\title{
A Heritage Interpretation-Based Itinerary to Enhance Tourist Use of Traditional Rural Buildings
}

\author{
Paola M. Leanza ${ }^{1,+}{ }^{\text {, Simona M. C. Porto }}{ }^{1, *}$, Vincenzo Sapienza ${ }^{2,+}$ and Santi M. Cascone ${ }^{2,+}$ \\ Received: 4 November 2015; Accepted: 29 December 2015; Published: 6 January 2016 \\ Academic Editor: Victor T. King \\ 1 Department of Agriculture, Food and Environment, University of Catania, S. Sofia n ${ }^{\circ} 100$, Catania 95123, \\ Italy; paola.leanza@unict.it \\ 2 Department of Civil Engineering and Architecture, University of Catania, S. Sofia n ${ }^{\circ} 64$, Catania 95123, Italy; \\ vsapienza@unict.it (V.S.); santi.cascone@darc.unict.it (S.M.C.) \\ * Correspondence: siporto@unict.it; Tel.: +39-095-714-7582; Fax: +39-392-303-1968 \\ + These authors contributed equally to this work.
}

\begin{abstract}
The study describes the planning strategy for a tourist itinerary in rural areas located in South-Eastern Sicily which aimed at promoting cultural rural heritage and diversifying the tourist offer. The planning of the tourist itinerary occurred within an appropriate heritage interpretation strategy as a working method which could facilitate the understanding and social use of the heritage sites located along the itinerary. The tourist itinerary combined significant territory potential such as traditional rural buildings and enogastronomy. It included a starting point; which is a heritage site and an already well known "tourist attraction", and several other tourist resources selected on the basis of the information derived from the analysis of the profile of the average visitor to the area. An interpretation center, which was located at the heritage site, and several interpretation media placed at each stopping point included in the itinerary supported the tourists during their trip. By promoting traditional rural buildings and enogastronomy, the tourist itinerary represents a significant opportunity for rural diversification and, therefore, can contribute to achieving sustainable socio-economic development of rural areas.
\end{abstract}

Keywords: rural tourism; tourist itinerary; rural heritage; territorial marketing; building materials

\section{Introduction}

The tourism sector promises to generate employment, improve infrastructure for the community, help to restore vitality to weak rural economies, increase the profitability of the most underdeveloped regions, improve the standard of living of the local population and encourage citizens to protect and enhance natural and cultural assets [1,2].

In particular, the development of rural tourism offers multiple solutions to problems facing rural areas by creating new jobs and multi-activities that can result in an increase in income. With regard to a socio-cultural point of view, rural tourism can promote the repopulation of rural areas and the preservation of crafts, customs and cultural identities. Furthermore, from the point of view of environmental protection, rural tourism can contribute to improving the quality of the natural habitat, built environment and infrastructure. The relationship between rural tourism and sustainability according to planning strategies and actions and the analysis of potentiality and limits for its impact on sustainable rural development are often argued [3,4].

According to Meyer [1], tourist itineraries are seen as good opportunities for the development of tourism in marginal areas that possess natural or cultural resources and can be defined and associated to each other by the presence of local products whose quality and reputation are essentially due to natural factors and human traditions of the geographical environment of origin [5]. Some studies on 
planning itineraries in different environmental fields are carried out with particular attention to the overall strategies of economic planning and to the involvement of stakeholders [6].

The overall objective of the present study is to propose a heritage interpretation-based itinerary (HII) able to influence tourists who visit a famous rural heritage site, to extend their stay in the related neighbouring rural area and, as a consequence, consume tourist products. In this paper, the $\mathrm{HII}$ is defined as a tourist itinerary that is supported by suitable interpretation media and connects several heritage attractions located in a given rural area with a heritage site selected as a tourist catalyst. The term "interpretation" refers to the set of actions aimed at strengthening public awareness regarding a particular heritage site and improving its understanding [7].

Tilden [8] stated that the aim of interpretation is not instruction, but provocation, i.e., a process that stimulates the mind of a visitor through meditation and leads to the emergence or strengthening of a feeling. This process on one hand allows visitors to enjoy the new knowledge and develop a positive attitude towards the protection and conservation of cultural heritage sites and on the other hand favors the promotion and marketing of heritage sites in respect to authenticity and integrity [9-12].

In this context, the place where tourists are accommodated can arouse emotions and feelings through which they are encouraged to return to visit a specific geographic area. In rural areas, the traditional rural buildings (TRBs) can represent a cultural heritage capable of arousing such emotions and feelings and are often converted for purposes of making accommodation, food services and agricultural activities available to tourists [13-15] and for the economic, social, cultural and landscape benefits to the rural community $[16,17]$.

The choice of the TRBs as a theme of the itinerary is the novelty of the present study because, in the literature of the tourism sector, several studies have focused on tourist itineraries based on historic city-buildings whereas only a few have regarded traditional buildings located in rural areas.

The implementation of a HII by following the method proposed in this study should promote the dispersal of tourists and, in turn, the dispersal of economic benefits to marginal areas that, in spite of having considerable environmental and cultural significance, do not have tourist services (e.g., rural viability, transportation, and accommodation) for suitable tourism development [1].

\section{Materials and Methods}

\subsection{Developing a Heritage Interpretation-Based Itinerary}

Tourist itineraries are characterized by the mix of natural, cultural and social resources that convey a distinctive character to the rural areas where the itinerary is located [5]. Heritage is a significant part of a tourist itinerary and the concept of a heritage route is mainly used in the framework of the promotion of rural tourism $[18,19]$.

A HII seeks to articulate a set of meanings that endows it with a distinctive identity. Such meanings are provided by heritage interpretation plans and their connection with tourists are defined within suitable heritage interpretation strategies [20].

To develop a HII the phases reported below must be carried out:

(1) Selection of the starting point of the HII. A specific heritage site which is already considered as a "tourist attraction" must be selected as the starting point of the HII. This stage is crucial because, as stated by Prideaux [21], "large well-known attractions create visitor interest in an area and may constitute the primary drive for a visit".

(2) Analysis of the visitor profile. To develop a HII, the profile of the visitors must be established. Nationality, education, income level, experience and daily budget are the major factors influencing the duration of stay. These factors have an impact on the duration of the stay as it emerges from studies on the length of stay of travelers [22]. Examples of visitors' profiles can be found in several studies on wine tourism where the general characteristics of potential tourists, which included demographic data and behavioral attitudes on the purchase of products, were investigated [23]. 
(3) Choice of the interpretive elements on the basis of the analysis of the visitor's profile. The heritage site selected as starting point of the HII must provide visitors with a number of interpretive elements (e.g., history, socio-economic context, environmental features, and building techniques) that link it to other TRBs.

(4) Implementation of an interpretation center which will be located at the heritage site selected as a tourist attraction. The interpretation center will ensure the mediation between visitors and the rural area. At the interpretation center, visitors can gather general information on the area with regard to natural and cultural resources, customs and ways of life of the local community. This phase of the method involves the production of interpretation media to be placed at the interpretation center. The type of interpretation media must be previously selected from among those possible [11] during the planning phase of the heritage interpretation plan [20]. The contents of the interpretation media must be consistent with the interpretive elements provided by the heritage site selected as a tourist attraction. Other interpretation media should be placed in each TRB included in the itinerary as stopping points on the tour, which provide both information about the site and the "interpretive elements".

(5) Implementation of a geographical information system (GIS) to store geographical data and other attributes which characterize the heritage site selected as a tourist catalyst and the TRBs [20]. This kind of system is a useful tool to carry out several relevant analyses: TRBs' distance from the heritage site selected as a tourist catalyst, TRBs' mutual distance, characteristics of the viability (e.g., slope and type of road surface), information on the services offered to tourists along the itinerary such as places to taste food products, eat, stay, and where to find picnic areas and other services. In this context, over the years, food and beverages have become the most important components of the tourist experience [24]. By promoting local products, food and tourism represent a significant opportunity for rural diversification [23-25] and, therefore, can contribute to achieving one of the objectives of multifunctional agriculture: the socio-economic development of rural areas [26].

(6) TRBs connections through the HII. The number of kilometers which visitors are able to travel in a day (about 180/200 km) [5] should be taken into account in the selection of TRBs' connections. The perception of geographical distance may be affected by the morphology of the territory (e.g., shape of the paths, winding roads, presence of slopes, shrubs, road signs, and natural landmarks) and any cultural differences between the visitors' places of origin and the tourist destination [5]. The distance perceived by the tourist is a mental representation of the actual distance formed on the basis of the social, cultural and life experiences of an individual that has the power to increase or decrease the cognition of the cost of transport and has an important role in the choice of a holiday destination $[21,27]$. If the destination of the trip is particularly attractive to the visitor, the presence of routes in the itinerary where the distance perceived by tourists is greater than the geographical one does not have a dramatic impediment on the carrying out of the tour [28].

The method proposed in this paper was applied to develop a HII in South-Eastern Sicily (Italy) in the area of the Hyblean Plateau.

The final objective of the study was to implement the actions of learning of the heritage interpretation strategy [20] developed within a pilot project of the Archimed programme of the Community Initiative Interreg III B, entitled “Tourism Uses of the Historic Environment. Know-How Transfer and Quality Management Practices at Community Level", commonly referred to as Herodot.

\subsection{The Area of Study}

The itinerary is located in the Province of Ragusa in Sicily (Italy) and is close to the coastal area which attracts a large influx of tourists in the summer season due to seaside tourism. 


\subsubsection{Tourist Flows in the Province of Ragusa and Tourist Accommodations}

In the Province of Ragusa between the years 2011 and 2012, tourist arrivals and stays totaled 208,319 and 816,438, respectively (data released by the Department of Tourism, Sport and Entertainment of the Region of Sicily). The analysis of the data shows a clear predominance of internal tourism (visitors resident and non-resident within the Italian country) because only about $29 \%$ of the tourist arrivals and $36 \%$ of tourist stays were foreign tourists. Among Italians, as seen by stays and arrivals, Sicilians are the major visitors to the province, followed by visitors from Lombardy, Latium and Campania. Among the foreign tourists, French tourists were the greatest number of visitors, followed by those coming from Germany, Switzerland, United Kingdom, Belgium, Israel, Netherlands, United States of America, and Russia.

An increased influx of tourists is generally recorded in July, August and September in comparison to the other months of the year. Therefore, from this analysis, the importance of a seasonal adjustment in tourism emerges because it is mostly centered on accommodation in resorts located along the coast.

During the considered time interval, tourist accommodation facilities amounted to 480, and were divided into hotels (95), which are located mainly in the coastal area and in urban centers, and other types of accommodations (385) such as camping, holiday parks, rentals, farmhouses, bed \& breakfasts and other accommodation. The number of beds available in the considered accommodation amounted to 10,566 for the hotels and to 5790 for the other type of accommodation. With regard to tourist accommodation in rural areas, a total of 524 beds were present in 26 farmhouses as well as a conspicuous number of bed \& breakfasts.

As it emerges from stays and arrivals, tourists had a preference for hotels.

\subsubsection{Main Tourism Attractions in the Area under Study}

The Baroque Architecture

The baroque designs of the cities of Modica, Noto, Palazzolo Acreide, Ragusa Ibla, Scicli, Catania, Caltagirone and Militello Val di Catania, located in South-Eastern Sicily, has been included by UNESCO in the World Heritage List because they represent a considerable collective achievement, successfully carried out to a high standard from an architectural point of view. Built according to the late baroque style, they also show particular innovation in urban design and in the actual building of the city.

\section{The Ruins of Kamarina}

The area of study is close to the ruins of Kamarina, a city which was founded by the Syracusans at the beginning of the sixth century B.C. (598-597 B.C.) on the fertile promontory between the Ippari and Oanis rivers (nowadays called Rifriscolaro) with the intent to create a passage to the African route and to control the southward expansion of the town of Gela.

The Regional Archaeological Museum of Kamarina is among the most interesting in Sicily, for both its wealth of collections and location. The museum is situated in the archaeological area of the ancient city of Kamarina $35 \mathrm{~km}$ from Ragusa.

The museum is a rural building from the nineteenth century, and a significant example of an agricultural residential typology which is very common on the Hyblean coast. The construction is made up of different buildings organised around a central space which is open on two sides and faces towards the countryside. It is located on the acropolis where the temple of Athena once stood and the ruins can still be found inside one of the rooms of the museum. The museum illustrates the political, civil and economic history of the city of Kamarina, its urban development, the most important monuments, and the material and artistic production.

\section{Natural Attractions}

In general, protected natural areas are important resources because, by being an important destination for leisure, they may become tourist catalysts for the territory where they are located. 
In the Province of Ragusa, two natural regional reserves currently exist: the Riserva Naturale Orientata "Pino d'Aleppo" near the city of Vittoria and the Riserva Naturale Speciale Biologica "Macchia Foresta del Fiume Irminio" near the city of Marina di Ragusa.

Wine and Food

Wine and food tourism represents a form of cultural tourism. In fact, through the preservation and enhancement of agriculture and wine growing territories, wine and food tourism offers a new way to experience a holiday. Another important aspect of wine and food tourism concerns the fact that it favors the equal distribution of the tourist flow because it is available all year round.

The various climatic conditions in Sicily are favorable to wine and food tourism. In fact, a wide variety of cultivation and breeding supply the basic products for the wide array of typical Sicilian dishes which are strongly bonded to the territory. Local agricultural products can be divided into the following categories: products of protected nomination (DOP), products of protected geographical indication (IGP), and traditional products.

Organized visits to wineries allow tourists to taste wine, typical products and local dishes. Furthermore, tourists have the opportunity to experience the place by participating in local product processing.

\section{Results and Discussion}

\subsection{The Starting Point of the HII}

The heritage site selected as the starting point of the HII was Donnafugata Castle, a building of considerable historical and architectural importance within the Province of Ragusa (Figure 1). The Castle is an important tourism catalyst for a variety of reasons: it is an important place for social and cultural events (e.g., Cheese Art, antique exhibitions); the Castle has a social and cultural relevance because it was the residence of the baron Vincenzo Arezzo who was an important figure in the political circles of Eastern Sicily in the 19th century $[29,30]$. The tourist flow to the Castle amounts on average to approximately 5000 visitors a month.

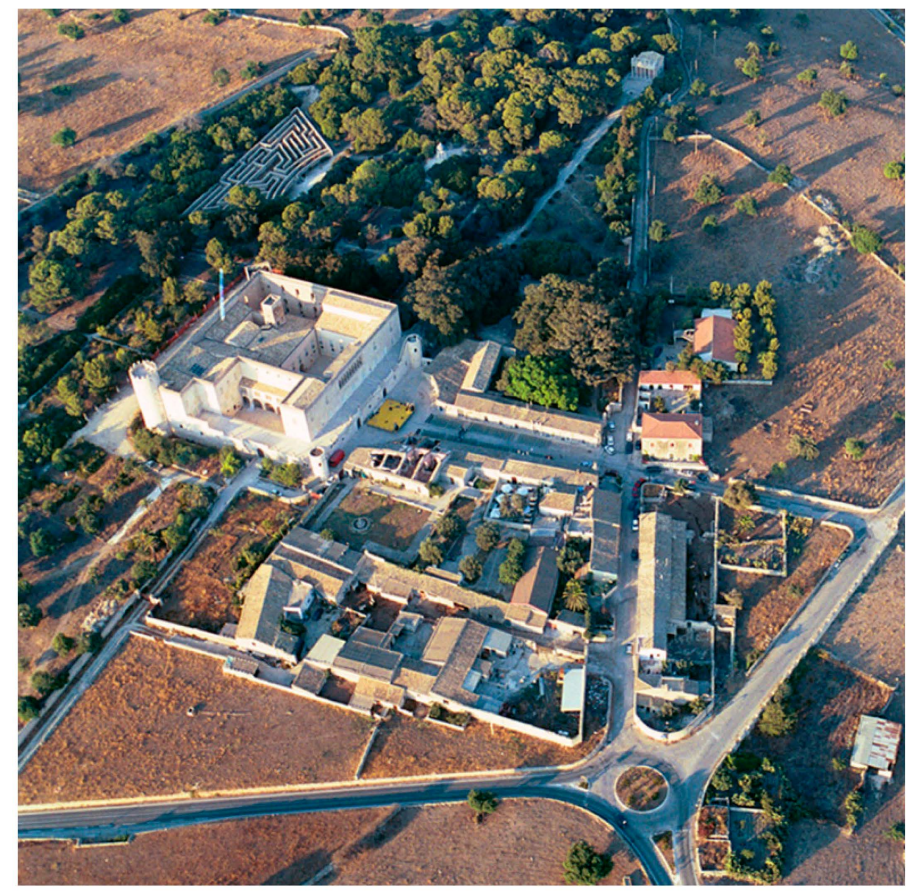

Figure 1. View of Donnafugata Castle (reproduced with permission from F. Ingallinera) [31]. 
The Castle is located about $20 \mathrm{~km}$ from Ragusa city and a little farther from Ibla, the old city which was built on the ancient urban centers of Ragusa and attracts millions of visitors from around the world as a sublime example of Sicilian Baroque; less than $15 \mathrm{~km}$ from the coast of Ragusa; about $10 \mathrm{~km}$ from Kamarina Museum; about $10 \mathrm{~km}$ from a farm associated with the wine road "Cerasuolo di Vittoria dal Barocco al Liberty"; about $15 \mathrm{~km}$ from a farm in the Irminio valley, associated with the consortium "Monti Iblei" which was established for the protection of extra virgin olive oil.

Concerning the architectural features, the Castle was originally a fortified farmhouse in the 18th century, built on the ancient buildings from the 10-11th century. The entrance to the Castle is preceded by a wide path, on both sides of which, in addition to the storehouse and the cowshed, are the homes of the peasants who worked for the baron. The Castle has been subject to various transformations throughout the decades. The oldest part of the building is the massive square tower situated in the center. The Castle is fronted by a long terrace above the main entrance. At both ends, two circular towers arise, which are accessible by narrow stairs. The terrace leads to the great tower on one side and on the other to the wide and sumptuous staircase that leads to the park. Beyond the terrace, there is a Gothic-Venetian style loggia which was built at the beginning of the XX century. Underneath, there are large pointed balconies in the same style as the loggia. These are decorated with beautiful sculptures and motifs that recall the Roman bestiary alternated with beautiful female figures. On the other sides of the Castle, there are many double lancet windows and two towers. The first tower, built between 1950 and 1960, has a square base and stairs made of hard limestone. The second tower, taller than the first, has a circular base and wooden stairs. Between the two towers, in addition to many windows, there is a moat like those found in ancient castles.

Inside the Castle, passing the main gate, there are storehouses on the left and a chapel on the right. The interior of the chapel, though simple, with its barrel vault and suffused light, creates a sense of mystical serenity.

In the large yard, there are four entrance arches, many doors, balconies and windows. In the main room, a flight of stairs made of pitch stones and adorned with benches, vases and statues leads to the floor where the noble family lived. The statues include a discobolus on the ground floor and two neoclassical style female figures on the intermediate flights.

\subsection{Analysis of the Visitors' Profile}

The profile of the "average" visitor was defined by analyzing the answers given by tourists visiting Donnafugata Castle in a double-language questionnaire. The questionnaire was distributed to the visitors before they began their visit [20].

The data from the questionnaire showed that visitors to the Castle are mostly Italians, are aged between 41 and 61 years, have a good cultural background, stay in the area for 1-3 days, are self-organized tourists, and use personal cars as their main means of transport. From this data, it emerges that Donnafugata tourists may decide to extend their visit to the Hyblean area when organizing their holiday which is mostly carried out without the aid of tour operators and, therefore, not subject to time constraints.

From the analysis in the questionnaire, the majority of visitors (74.6\%) preferred coastal areas as places of accommodation and only $11.3 \%$ of tourists chose farmhouses as places to stay. The aspects of the area that most strongly provoked tourists' curiosities were its gastronomy $(41.3 \%)$ and rural architecture (33.0\%). Moreover, visitors would have a higher knowledge of the architectural characteristics of TRB [20], which in this study became the elements to be interpreted in the HII. The itinerary was addressed to tourists aged at least 14 years old and especially coming from Sicily, in order to raise awareness of the protection and enhancement of the TRBs of the island. Furthermore, the itinerary was also addressed to heritage tourists, i.e., those visitors of the middle class, well-educated and middle-aged. Generally, these kinds of tourists plan their holidays away from their place of residence by collecting information on the site they will be visiting on their journey and are more willing to spend money on travel [21]. 


\subsection{Choice of the Castle's Elements to be Interpreted}

Among the many interpretive elements that the Castle could provide, only the building materials and techniques used in its construction have been considered in this study. If knowledge of these interpretive elements is properly widespread among visitors, it might inspire tourists to learn more about a particular cultural trait of the local community that, in this case, is the manner of building which was influenced by local environmental resources such as limestone, asphaltic stone and wood.

In this study, knowledge of the materials and building techniques applied in the construction of the Donnafugata Castle was deepened through the acquisition of drawings (e.g., maps, floor plans, tables, sections, and degradation maps) made available by the technical bureau of the Municipality of Ragusa. Information was also gathered by means of inspections and metric and photographic surveys.

Though the building typology of the Castle looks quite different from that of its neighboring TRBs, several architectural elements (e.g., floor, vault, roof) were made with the same materials and building techniques as those used in the construction of TRBs (Figure 2).

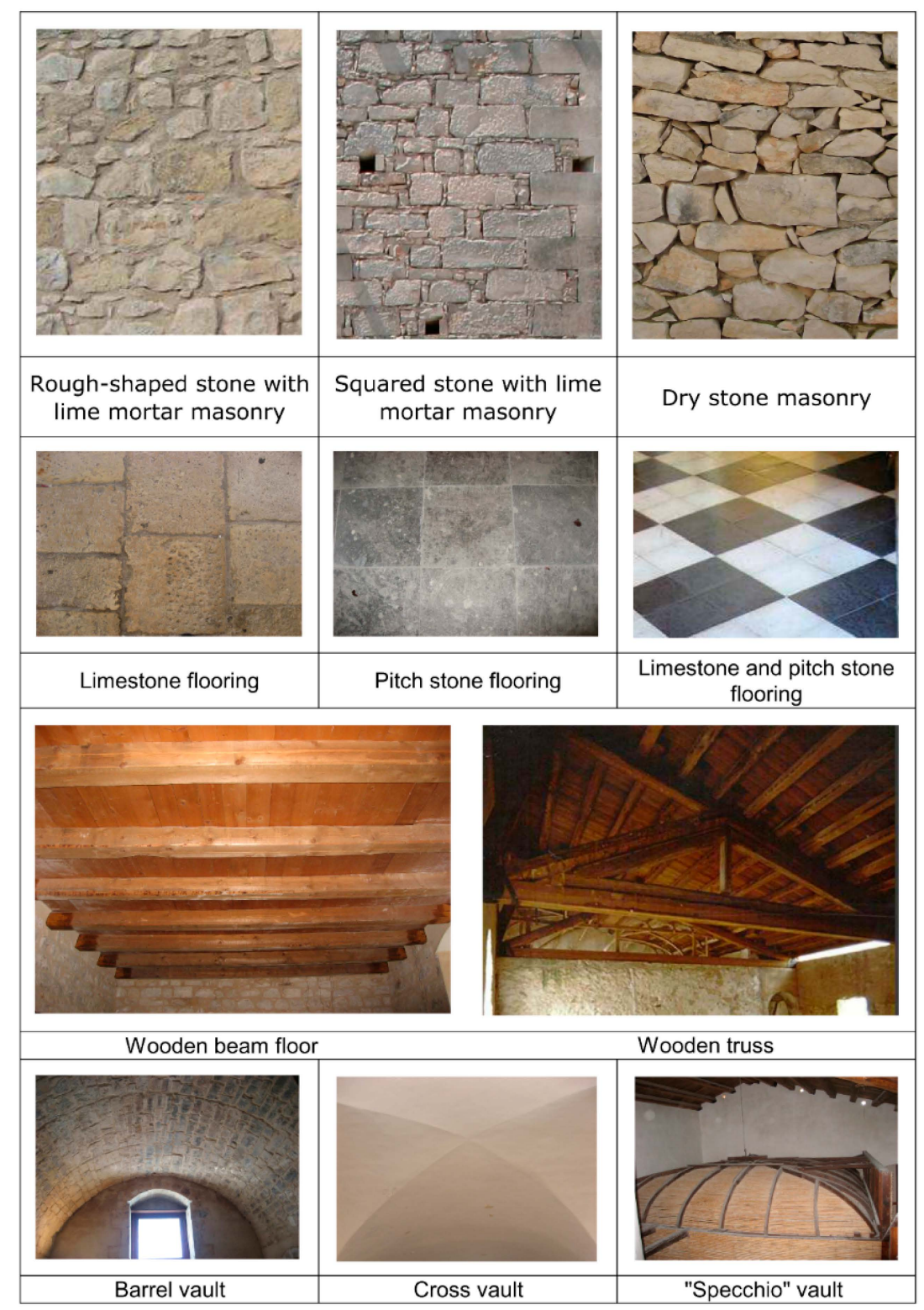

Figure 2. Materials and building techniques common to Donnafugata Castle and TRBs in its surrounding area. 


\subsection{Implementation of the Interpretation Center Located in the Donnafugata Castle}

Tourists of the Donnafugata Castle can visit the interior of the building which itself will serve as the interpretation center for the surrounding area. Here, tourists can obtain information on building materials and techniques used in the construction of the Castle and can have a look at the map of the HII with indications of the streets and stopping points.

The interpretation media placed at the Donnafugata Castle and at the stopping points of the HII were chosen on the basis of the results obtained from studies conducted in previous research [20] that had shown the degree of appreciation by tourists about the means of interpretation already in use at the Donnafugata Castle and those which may be integrated. Therefore, the interpretation media produced in the research described in this paper were: a didactic graphic panel to be placed at the Donnafugata Castle, the panels to be placed at the stopping points, and a mini-guide that tourists can take with them during the tour.

\subsubsection{The Didactic Graphic Panel of the Donnafugata Castle}

The interpretive elements of the Donnafugata Castle were made accessible to tourists through a bilingual (English-Italian) didactic graphic panel placed at the entrance to the building.

The panel was divided into two distinct sections: the first section (Side A) (Figure 3a) informed the visitors about the architectural details and building techniques of the Castle; the second section (Side B) (Figure 3b) illustrates the itinerary, which included the Donnafugata Castle and the rural buildings in the neighboring area.

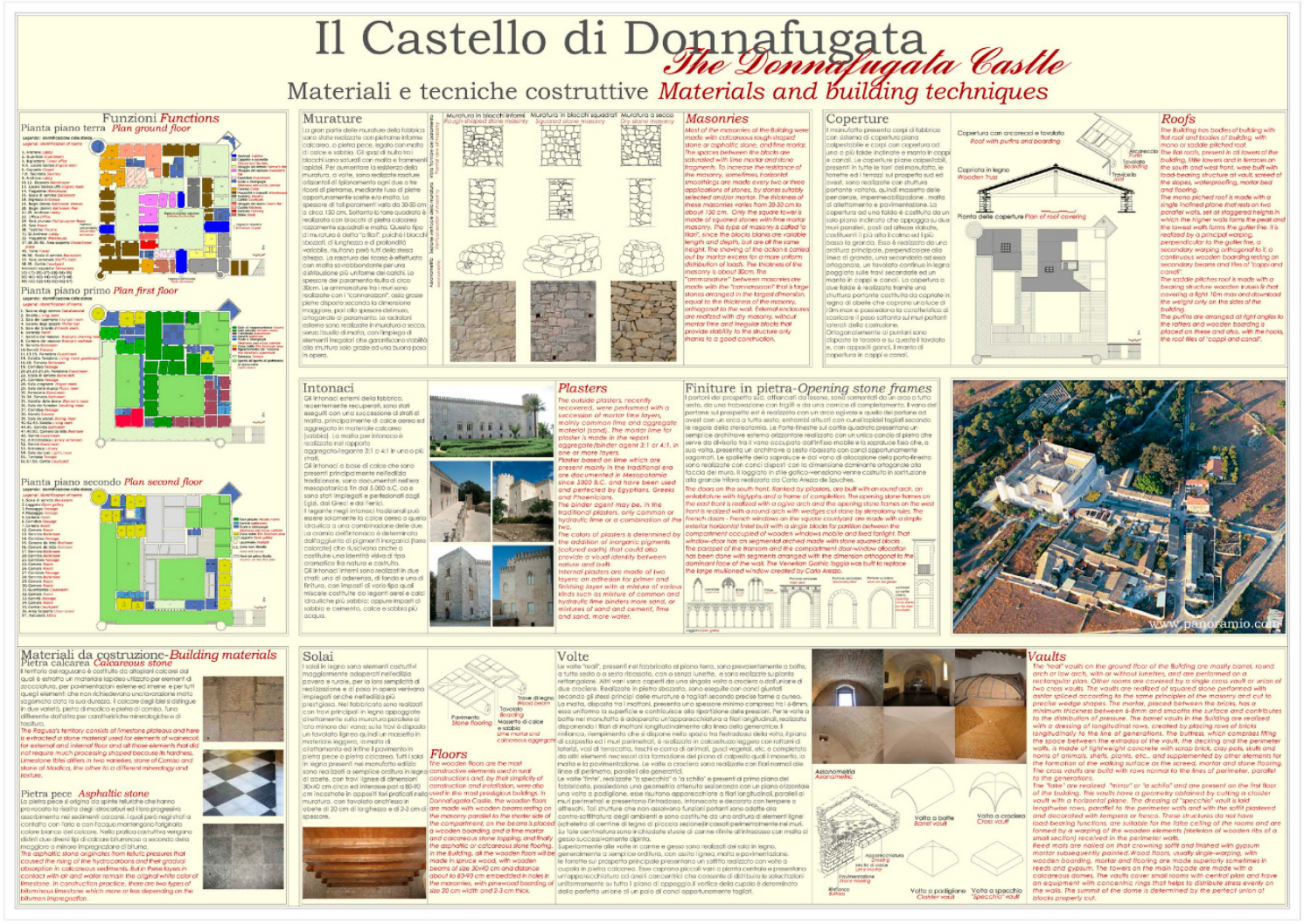

(a)

Figure 3. Cont. 


\section{Edifici Rurali Tradizionali}

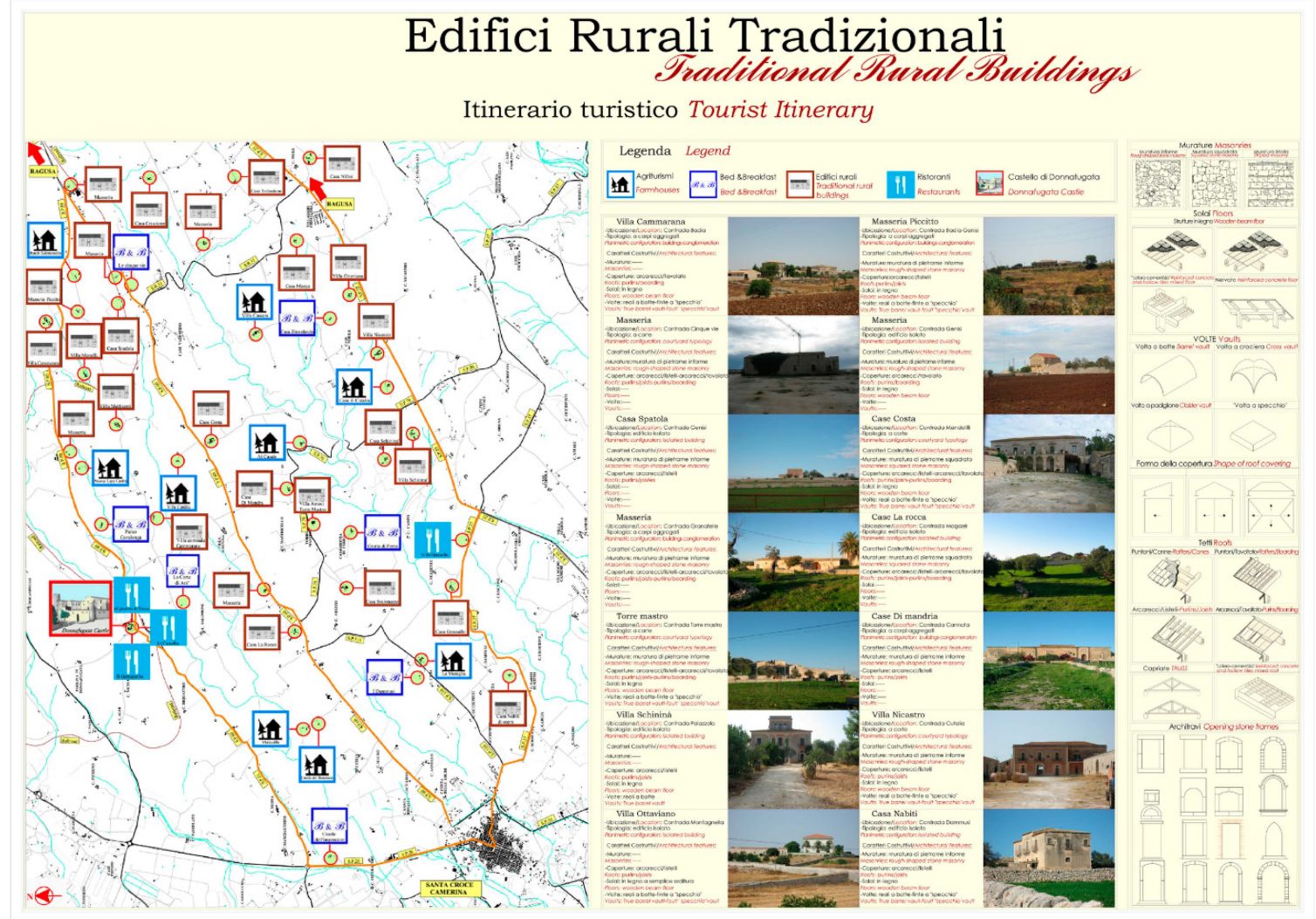

(b)

Figure 3. (a) The panel located at the Donnafugata Castle-Side A; (b) The panel located at the Donnafugata Castle-Side B

Side A of the panel illustrates the architectural details and building techniques that the Castle has in common with other TRBs in the area: masonries made of rough-shaped calcareous stones or squared stones and built using lime mortar and calcareous aggregates such as those found in all of the surveyed buildings; dry stone enclosure masonries made with rough-shaped calcareous stone generally used for small-scale building or for delimiting plots of land; external flooring made of calcareous stone that were found in 50\% of the surveyed buildings; internal flooring made of asphaltic stone, both polished and not polished, or calcareous materials that were found in approximately $90 \%$ of the buildings; floors made with boarding held up by wooden beams, as in $54.6 \%$ of the TRBs studied; wooden trusses like those found in $18.2 \%$ of the studied buildings; barrel vaults, with and without lunettes, made of the same calcareous stone as those found in $27.3 \%$ of the TRBs surveyed; decorative vaults made of bamboo canes, mortar of plaster and wooden frames into which the canes were nailed are like those found in $27.3 \%$ of the TRBs.

Guidelines made available by various studies [32] were followed for making the panels. The panel was A0 format and the background was pale yellow. The text was black (for Italian language) and red (for English language), the text font was "sans serif" and the body of the text was not smaller than 50 pt.

The itinerary was illustrated on Side B of the panel.

\subsubsection{Didactic Graphical Panels of the Stopping Points}

A tourist route may represent a tourist attraction by itself or requires the involvement of other activities to be attractive. It is widely demonstrated that the combination of the theme chosen for the itinerary with other issues may determine the involvement of those visitors that are not strictly interested in the subject matter of the route $[1,23]$. 
Therefore, in the design of the panels to be located at the stopping points of the itinerary, we tried to combine the theme of rural architecture with educational experiences related to other issues. Therefore, at each stopping point, the didactic graphical panel contained (Figure 4), in addition to information on building materials and techniques of the TRB present at the stop, information on: the enogastronomy (i.e., addresses and location of wineries where tourists can buy local wines or visit museums which display equipment used for the production of wine and oil by traditional processes; addresses and location of farms where tourists can attend the processing of local products such as cheeses, wine and oil); the archeology (i.e., distance from Kamarina museum and archeological areas); and Baroque architecture (i.e., location of churches and palaces which were included in the list of UNESCO World Heritage).

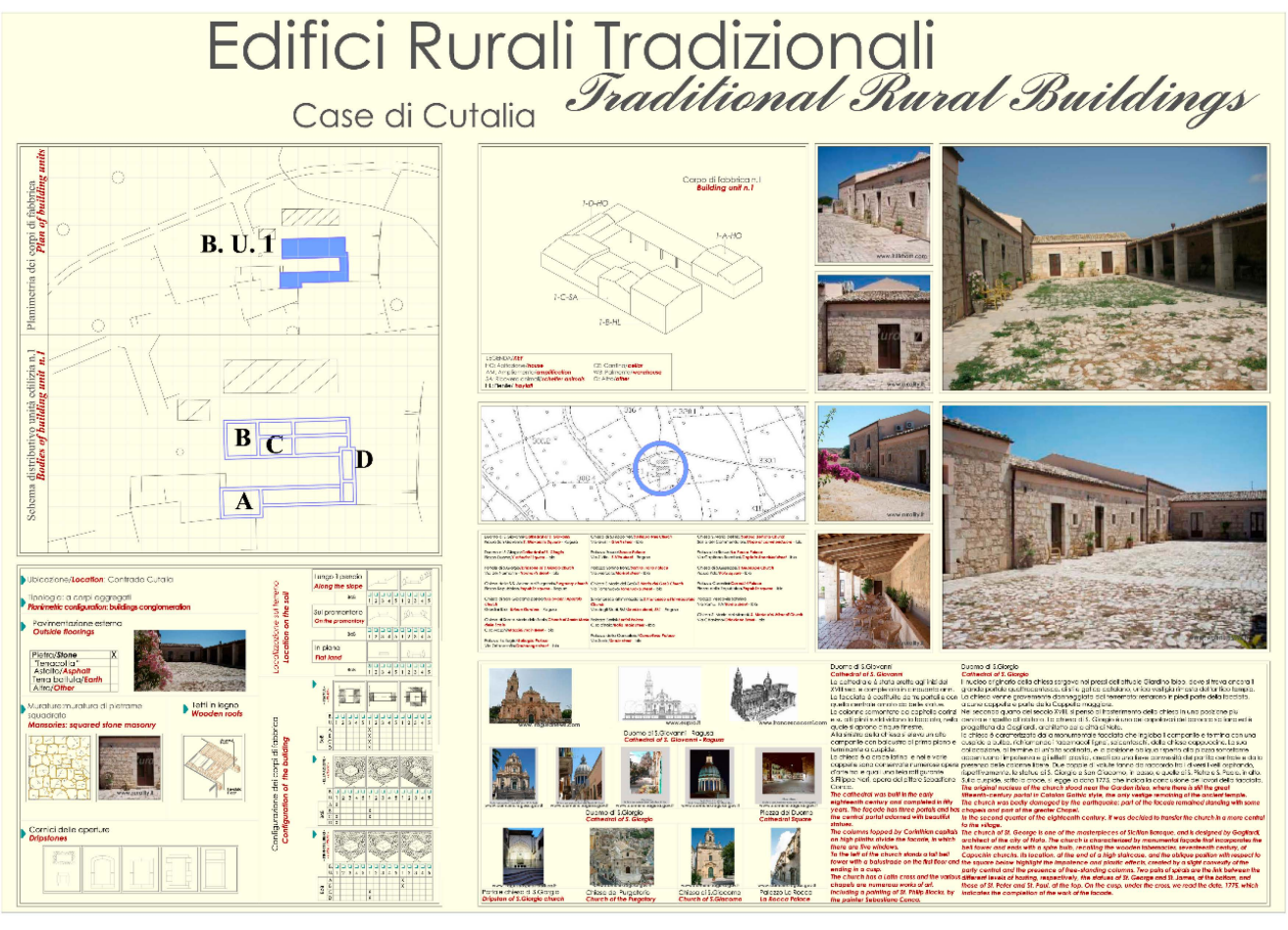

Figure 4. The panel located at the stopping point.

\subsubsection{Mini-Guide}

The mini-guide promoted a self-guided tour of the HII and added information on what could be experienced at specific stopping points $[11,33]$.

The orientation of tourists during the HII was supported by the mini-guide which, issued free of charge at the entrance of the Donnafugata Castle, was designed and implemented within the Interreg III B project and was part of a box that collected nine other mini-guides developed by the other partners of the project (Figure $5 a, b$ ).

On side A, the mini-guide contained information on the history of the Donnafugata Castle from its foundation to various transformations over the years, news on TRBs of relevant historical importance present in the area of the Castle and building materials and techniques that are common to the Castle and the TRBs. There was also information on the location of the Donnafugata Castle, the opening times to the public and the cost of the ticket.

On side B, the mini-guide showed the HII which reported the location of the stopping points. Furthermore, it contained a concise description of the itinerary, in particular of the roads to follow to take the tour, and a list of tourist accommodation facilities that collaborated in the planning of the tour. This side of the mini-guide also included an indication of the roads to Ragusa Ibla and the Archaeological Museum of Kamarina with a brief description of the place. 


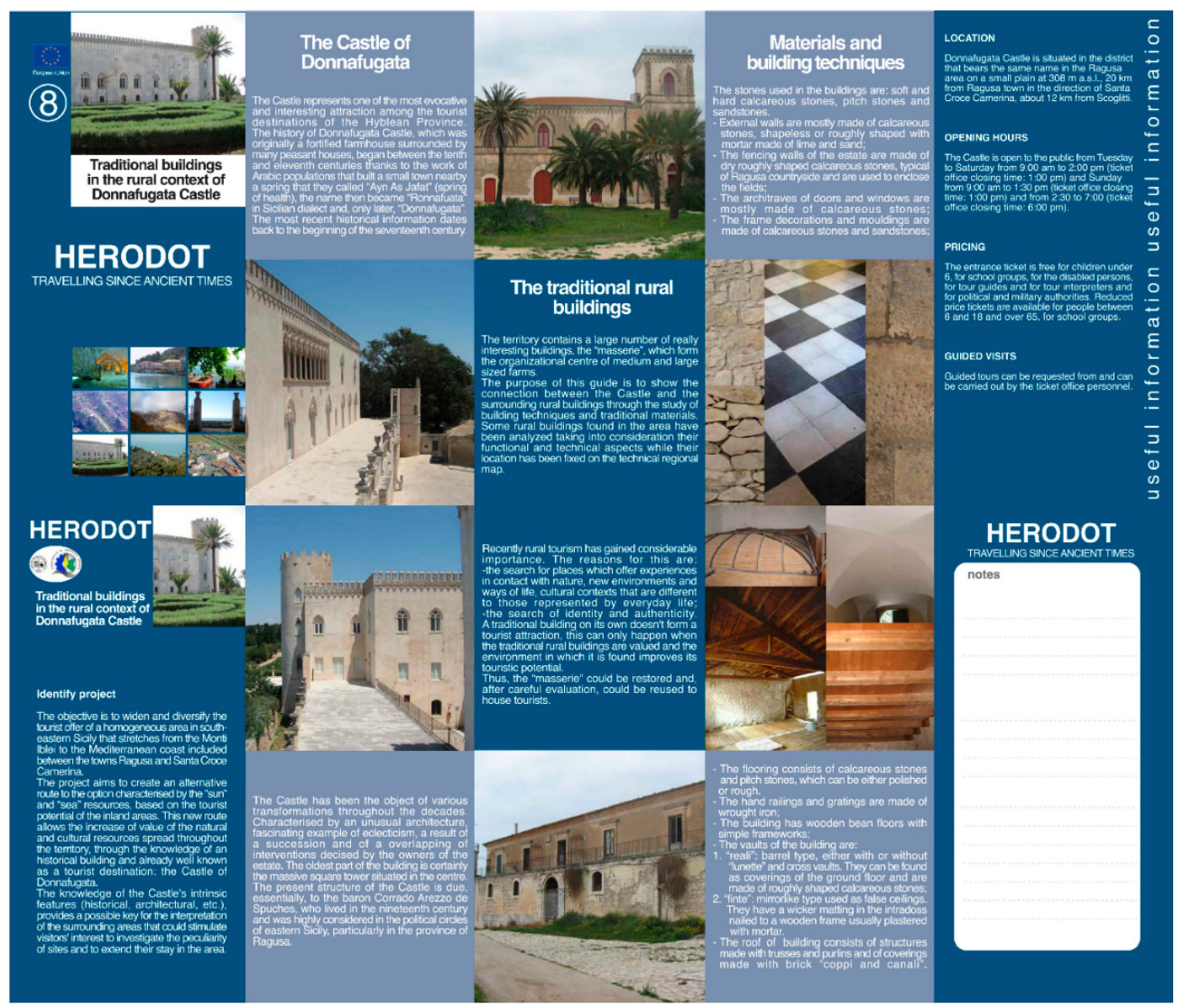

(a)

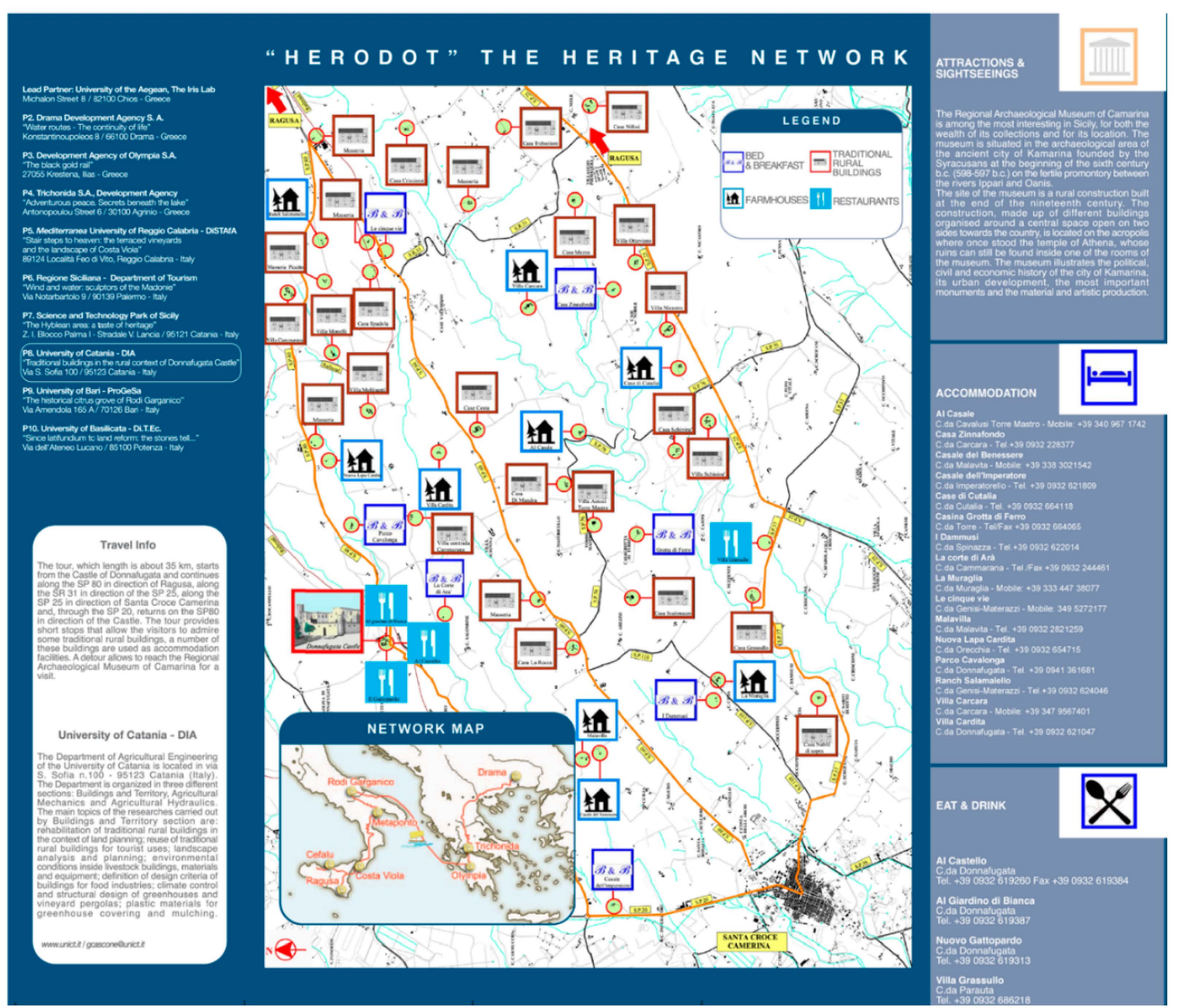

(b)

Figure 5. (a) The mini-guide—Side A; (b) The mini-guide—Side B. 


\subsection{Implementation of the Geographical Information System (GIS)}

The use of a GIS software made it possible to acquire, store, and display information about TRBs use, localisation, and building materials and techniques [17]; main and secondary road characteristics; and tourist accommodation located in the area near the Castle. Table 1 lists the attributes which were recorded in the thematic layer "building features" for each TRB of the sample.

Table 1. The building features of TRBs.

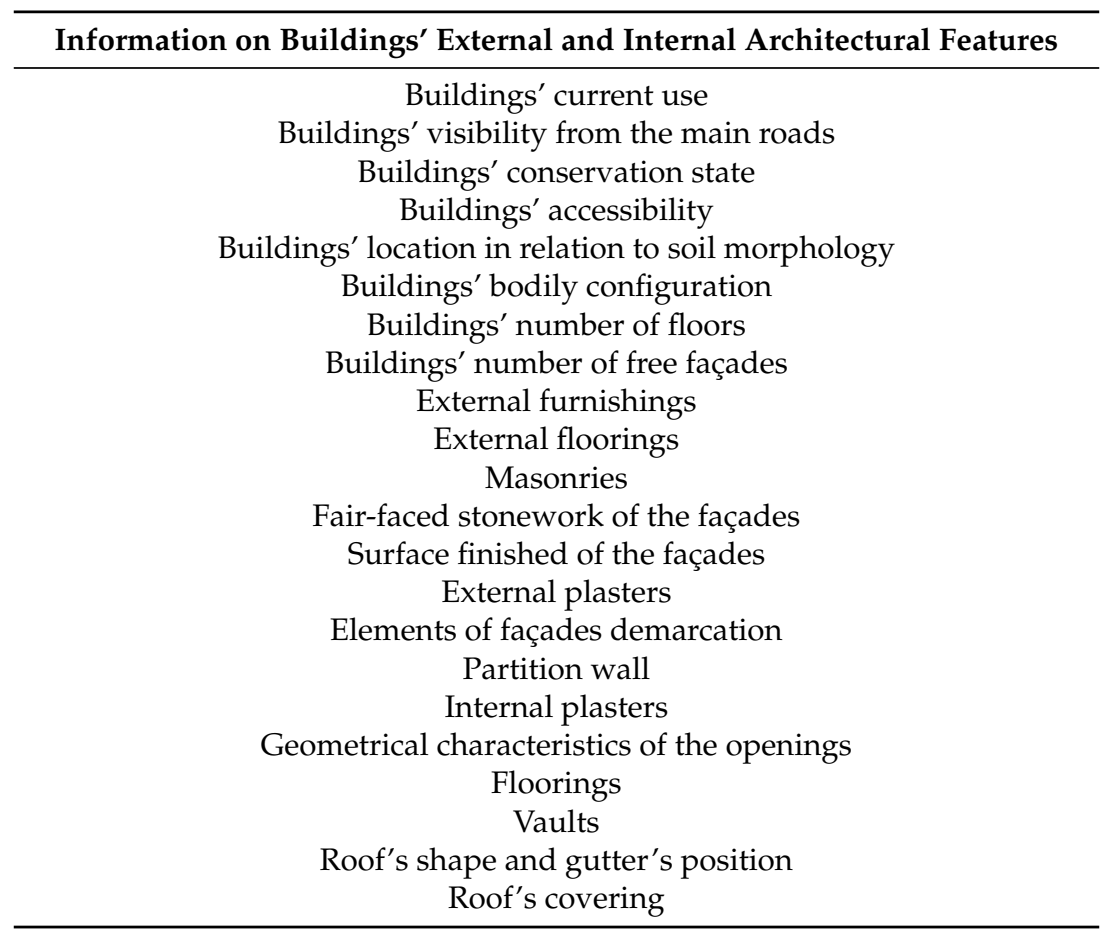

With the aim of studying the viability of the HII, the GIS used is Quantum GIS, a commercial package open source, which stores the following information on the main and secondary roads: geometric characteristics (width, slope, number and type of intersections, winding, paving); traffic flow parameters (flow and speed); traffic composition (light and heavy vehicles, pedestrians); type of users (regular or not); and the lighting conditions (day and night).

The data were collected by inspections in locus, by analysis of the Technical Regional Cartography, and the data from the Automobile club d'Italia.

With regard to tourist accommodation, the following data was included in the GIS: type of facilities (i.e., farmhouse, bed \& breakfast, hotel); availability of restaurants or facilities for food tasting; typical products offered to tourists; number of beds; cost per person for accommodation and lunch; location of picnic areas and swimming pools; services offered to children, elderly and disabled persons; availability of a kitchen to use; access to tour guides; possibilities for playing sport. In addition, the GIS included information on the use of the wireless system and if pets are allowed or not.

The tourist accommodation included in the itinerary were identified by data released by the Department of Tourism, Sport and Entertainment of the Region of Sicily, by Provincial tourism boards, by the official websites of the Ragusa city, and TripAdvisor. The tourist services' offered data were collected by the above mentioned sources and by websites for each accommodation.

The analysis of the Technical Regional Cartography of the Sicilian Region confirmed a significant presence of TRBs located in the neighbouring area of the Donnafugata Castle which amounted to 120 TRBs located in an area of approximately $112 \mathrm{~km}^{2}$ that extends from Ragusa to Santa Croce Camerina.

A sample of 46 TRBs was selected on the basis of historical, cultural and architectural relevance. 
A lot of the examined TRBs were made up of one-floor units of modest dimension (45.5\%).

The majority of the TRBs examined (81.8\%) had masonries made of rough-shaped calcareous stone and lime mortar; only a small number of the surveyed buildings $(18.2 \%)$ made use of square blocks calcareous stone and lime mortar. The original structure had been left untouched for the majority of the restored buildings. A significant number of the buildings $(63.3 \%)$ had at least one curtain wall plastered with lime mortar and calcareous pebbles, the surface of which had been textured using a sponge float.

With regard to roof shape, pavilions were used exclusively for buildings of significant importance $(18.2 \%)$, for instance, owners' houses, whereas traditional mono-pitched and double-pitched roofs, found in $72.8 \%$ of the buildings examined, were used to cover farm buildings and peasants' houses. With regard to roof structure, in $54.5 \%$ of the buildings, purlins, boarding, and battens were used to support traditional Sicilian tiles, also called "coppi e canali", which covered the roofs of the majority of the surveyed TRBs $(81.8 \%)$. In a few cases, builders had improperly substituted traditional Sicilian tiles with other non-traditional covering materials $(18.2 \%)$.

Nearly all of the buildings $(90.9 \%)$ had external floorings made of local calcareous stone, or, in rare cases $(9.1 \%)$, "terracotta" bricks.

The floorings of the rooms were frequently $(36.4 \%)$ made of more than one material. In the buildings surveyed, stone, "terracotta" and ceramic floorings were found. Several buildings examined (63\%) had partition walls made of stone.

Finally, rooms on the first floor included vaults and wooden floors, respectively, in $27.3 \%$ and $36.3 \%$ of the surveyed buildings.

Firstly, the itinerary included all the TRBs which were protected by the Superintendence of Cultural and Environmental Heritage of Ragusa and, secondly, the TRBs that were built with the same building materials and techniques as the Donnafugata Castle and had not been tampered with over the years.

Furthermore, the itinerary included the TRBs which were previously converted into tourist accommodation (farmhouses, bed \& breakfasts and restaurants) and, therefore, were available to tourists for lunch, accommodation and tasting of typical local products. Six farmhouses, six bed \& breakfasts, for a total of 184 beds, and four restaurants were included in the itinerary. The amount of tourist services offered by these structures are reported in Table 2.

Table 2. The accommodation services (AS) and facilities (F).

\begin{tabular}{cc}
\hline Type & AS and F Total \\
\hline Farmhouse (F) & 9 \\
Bed \& Breakfast (F) & 7 \\
Restaurant (F) & 4 \\
Beds (AS) & 243 \\
Picnic area (AS) & 11 \\
Swimming pool (AS) & 5 \\
Play ground and services for children (AS) & 2 \\
Sports facilities (AS) & 11 \\
Local products tasting (AS) & 9 \\
Free use of kitchen (AS) & 5 \\
Wi-Fi service (AS) & 4 \\
Tourist guide service (AS) & 5 \\
Pet allowed (AS) & 6 \\
Parking (AS) & 20 \\
\hline
\end{tabular}




\subsection{TRBs Connections through the HII}

The area of the itinerary was about $51 \mathrm{~km}^{2}$ and was enclosed by a perimeter of about $35 \mathrm{~km}$ which was formed by the main roads SP20, SP37, SP25, SR31, SP80, SP21 (Figure 6) that were paved and in good condition. The TRBs' distance from the Castle ranges between $1.6 \mathrm{~km}$ and $18.5 \mathrm{~km}$.

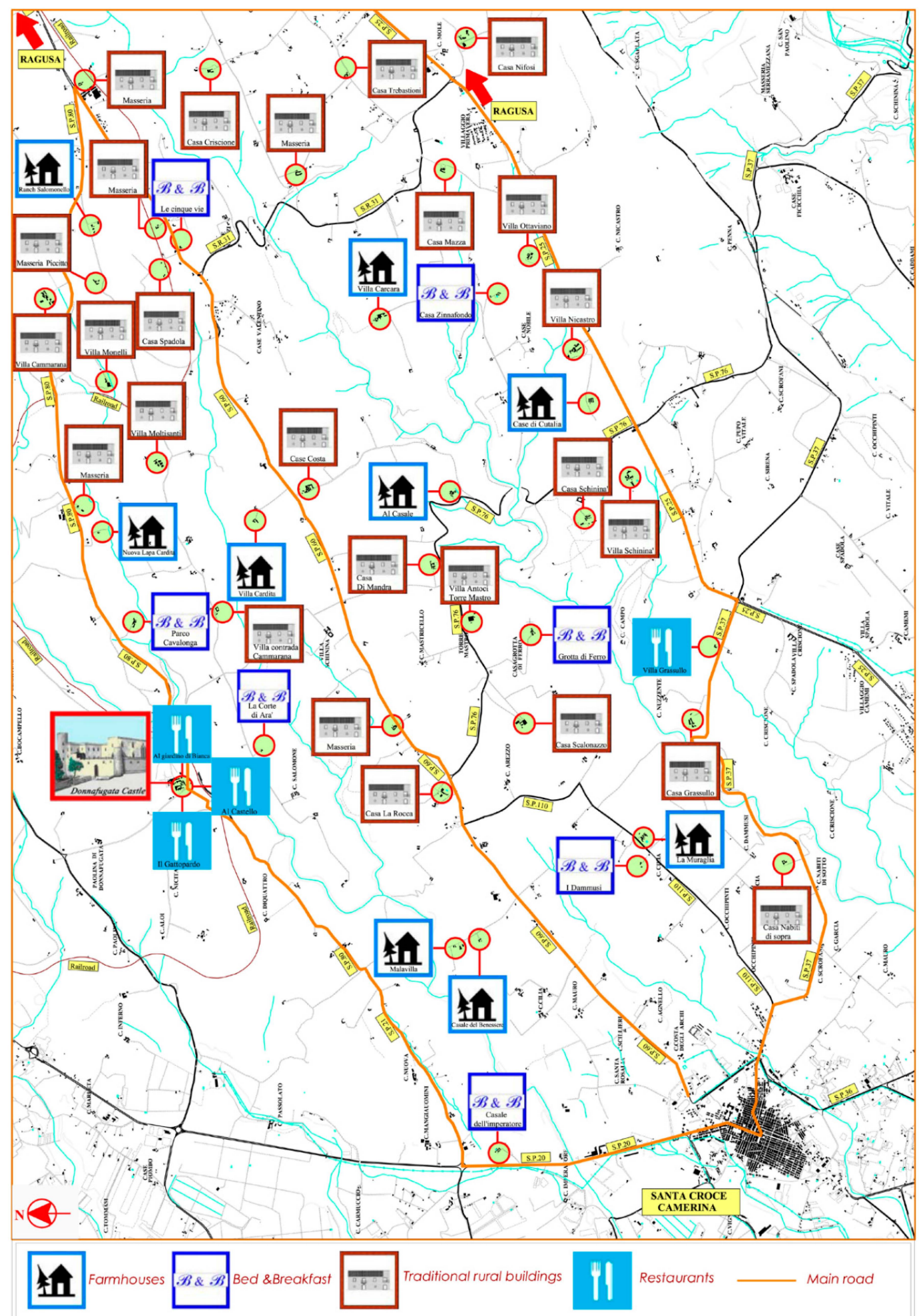

Figure 6. The area of the itinerary. 
On the basis of data collected in the questionnaire [20], the car is still the most widely used means of transport. This is supported, as observed by other authors [34] by the fact that it is easily available to the visitors. It is advantageous because it creates independence and flexibility in time management. The use of cars is mostly due to a greater extent to the lack of public transport or inadequacy of the transport system. Presently, in the area of the itinerary there are no public transportation lines that connect the Donnafugata Castle to the town of Ragusa and seaside villages. A private transportation company connects Ragusa city and the seaside resorts with the Castle in about $20 \mathrm{~min}$, twice daily.

In addition to the means of transport used by tourists, for the implementation of the connections of the HII the eligible kilometers that visitors are able to travel on a day trip were considered as well as the time required to cover their distances. The kilometers were counted using Google Maps and data collected by ACI and it considered the distance traveled by tourists on the main roads starting from their accommodation, travelling to the Donnafugata Castle, following the tourist itinerary, and returning to their accommodation.

Ultimately, the visitor can follow the itinerary by car on the roads that circumscribe the area or can go into and visit the stopping points on the road SP60 $(11.0 \mathrm{~km})$ or on the road SP110 $(4.4 \mathrm{~km})$ or on the road SP76 $(6.00 \mathrm{~km})$ or on a dirt road with a maximum length of $6.2 \mathrm{~km}$. Currently, road conditions do not allow the HII to be followed by bicycle. In fact, although the road network presented a traffic composition which predominantly consisted of light vehicles, maximum speed of distance less than $80 \mathrm{~km} / \mathrm{h}$ and transit of habitual users along almost all the connections in the itinerary, it is not equipped with lighting.

Electric minibuses may be employed for the transport of groups of visitors accompanied by tourist guides. However, this solution should be coordinated with the local authority that currently manages the Donnafugata Castle and should provide for a greater involvement of qualified tourist guides who currently, as detected by the questionnaire [20], are rarely used by tourists.

The stopping points are generally accessible on foot from farm dirt roads which are a few hundred meters long.

The perceived distance is not greater than the geometric one which amounts to about $56 \mathrm{~km}$. This is because of the relatively low slope of the roads on the itinerary, the few road crossings, the high visibility of the landscape along the roads determined by the sparse and low vegetation, the high visibility of the buildings chosen as stopping points of the road network, and the view of the sea.

By considering the length of the connections, the HII can be classified as a "single destination" for tourists whose accommodation is placed within the Province of Ragusa or the municipality of Noto (Province of Siracusa) and Caltagirone (Province of Catania). In fact, in a whole day these tourists travel a maximum 180-200 km. This implies a reduction of costs for visitors and a modest tourist service demand in comparison to those itineraries which are to be followed in several days. The HII can also be classified as "multiple destination" [35] for tourists coming from geographical areas in which distances from the Castle are more than $90 \mathrm{~km}$. In this case, these tourists are accommodated by the tourist facilities located along the itinerary and they can visit other tourist attractions such as the archaeological site of Kamarina, Ibla which is the old town center of Ragusa, and the wine museum "Valle dell'Acate".

The cost of the HII mainly depends on the distance to be travelled, the means of transport used [21], the cost of the ticket to the Castle, and the type of services used by tourists. Tourists can decide to have a lunch break and taste many typical dishes of Ragusa as well as local products such as fruits (e.g., oranges Navel, Tarocco and Sanguinello, tangerines and lemons), cheeses (e.g., provola Ragusana, caciocavallo Ragusano, ricotta), wines (Cerasuolo di Vittoria, Nero d'Avola, Ambrato di Modica, Albanello), and olive oil.

Possible further improvements of the method to enhance the HII:

(1) During the planning of a HII, the quality of the roads is crucial along with panoramic views, the presence of traffic signals [28] and services at tourist stops [1]. However, in the examined rural 
area, the illumination of the roads should be improved in order to improve visibility and road safety and, in turn, broaden the type of means of transport that can be used by tourists.

(2) The number of HII connections could be enlarged by taking into account judgments of preference expressed by tourists and residents on main and secondary roads currently present in the area under consideration. This may be implemented through the use of questionnaires, by conducting interviews and showing photographs for the assessment of the quality of natural and cultural resources found along the main and secondary roads [36,37]. The number of connections of the HII could be further expanded through the building of new paths. To this end, it is necessary to analyze the ground morphology and calculate suitable indicators [38] which permit the choice of the most appropriate means of transport by quantifying the degree of difficulty of the covered distance.

(3) The availability of tour guides at the selected heritage site is crucial because they act as intermediaries between tourists and an unfamiliar environment, thus playing an important role in the success or failure of a tour experience and influencing tourists' perceptions of the host destination [39]. For this reason, there are many studies on how to improve the work of tourist guides [39-42], on the different roles and functions that a tour guide can take on [42], such as the role of cultural mediator [41] and as "cultural heritage interpreters" [40]. The quality of the service offered by the tour guide can be measured by importance performance analysis (IPA) models [42] and improved by studies on emotional intelligence [41], which is universally recognized as a means to achieve success in personal and professional fields [39].

(4) In this study, the tourist profile was investigated before the trip (for planning the tourist itinerary), and it would be advisable to review it when tourists make their first evaluations (i.e., during the itinerary) as well as at the end of the tour when they make the final assessments and are better able to gauge their future preferences [43]. The final assessment of the HII may be carried out by means of questionnaires or interviews and investigate the socio-economic characteristics of the tourists, the value of the tourism service (benefits gained and costs), the quality of the tourist services (analysis of the characteristics of a service capable of meeting visitors' needs), the degree of tourist satisfaction (perceived performance compared to expectations) [43-48], the relationship between reasons for the visit and the degree of satisfaction [49], and the relationship between service quality and satisfaction [50].

(5) The promotion of the HII must be done through the cooperation between public and private partners and the direct involvement of the local community [1]. Better advertising in magazines, newspapers, internet and in hotels and tourist development agencies may attract more visitors during the year and adjust the seasonal flow of tourists. The sponsorship of the tour will occur during the events that take place at the Donnafugata Castle (Cheese art event called "Night Castle", concerts, theater performances and painting and sculpture exhibitions).

\section{Conclusions}

The heritage interpretation-based itinerary (HII) proposed in this study was implemented by following a method that would allow tourists to explore rural areas by visiting traditional rural buildings (TRBs) at stopping points located along the itinerary.

The Donnafugata Castle was chosen as the starting point of the HII because it was close to tourist sites and is visited annually by a large number of tourists.

The analysis of the visitors' profile of the Donnafugata Castle was decisive in the choice of the elements of interpretation which formed the basis for the HII. Visitors to the Castle were mostly Sicilian and preferred tourist accommodation in the coastal area. In addition, they demonstrated curiosity about rural architecture and enogastronomy. Therefore, among the many interpretive elements that the Castle could provide, this study considered the building materials and techniques used in its construction. Certainly, the interpretive elements selected in this study represent only one possible link between the Castle and TRBs; socio-cultural, environmental, economic and geographical characteristics could be other subjects of interpretation. In the proposed HII, food and wine were joined to the main 
theme because the combination of various subjects of interest within a tourist itinerary led to the involvement of people with different inclinations and aptitudes.

An interpretation center was located within the Donnafugata Castle. A didactic graphical panel was chosen as the main interpretation media to be placed in a room of the Castle because it was preferred by the visitors to the Castle. Other types of interpretation media were a number of didactic graphical panels placed at each stopping point on the itinerary and a mini-guide, which was distributed to the visitors at the interpretation center and enabled tourists to carry out self-guided tours.

The use of GIS made it possible to locate TRBs, classify materials and construction techniques, and assess the road conditions in order to select the stopping points of the HII and the means of transport. The GIS also allowed the available main tourist services (e.g., restaurants and accommodations) that were included as stopping points to be located.

The GIS analysis showed that the area of the HII is equipped with a large amount of tourist accommodation which was economically advantageous and of good quality (farmhouses and bed \& breakfasts).

The study of the TRBs' connections has shown that the perceived distance along the itinerary is not much higher than the geometric one. In addition, considering the length of the connections, the tourist itinerary is a "single destination" for tourists staying in Ragusa Province or in the territory of the municipality of Noto (Province of Siracusa) and Caltagirone (Province of Catania) because the distance they are able to travel in a day is equal to $180-200 \mathrm{~km}$. However, for tourists who live more than $90 \mathrm{~km}$ away from the Donnafugata Castle, the HII may be a "multiple destination" because they need to use the tourist facilities included in the itinerary.

Acknowledgments: The study has been carried out within one of the pilot projects of the PIC-Interreg III, stand B, programme Archimed, 2007-2013, entitled, "Tourism Uses of the Historic Environment. Know-How Transfer and Quality Management Practices at Community Level". This project, also known as Herodot, was funded by the European Union.

Author Contributions: The authors contributed equally to this work.

Conflicts of Interest: The authors declare no conflict of interest.

\section{References}

1. Meyer, D. Tourism Route and Gateways: Key Issues for the Development of the Tourism Route and Gateway and Their Potential for Pro-Poor Tourism; Overseas Development Institute: London, UK, 2004.

2. Sharpley, R. Rural tourism and the challenge of tourism diversification: The case of Cyprus. Tour. Manag. 2002, 23, 233-244. [CrossRef]

3. Garau, C. Perspectives on Cultural and Sustainable Rural Tourism in a Smart Region: The Case Study of Marmilla in Sardinia (Italy). Sustainability 2015, 7, 6412-6434. [CrossRef]

4. Trukhachev, A. Methodology for Evaluating the Rural Tourism Potentials: A Tool to Ensure Sustainable Development of Rural Settlements. Sustainability 2015, 7, 3052-3070. [CrossRef]

5. Bruwer, J. South African wine routes: Some perspectives on the wine tourism industry's structural dimensions and wine tourism product. Tour. Manag. 2003, 24, 423-435. [CrossRef]

6. Antonson, H.; Steen Jacobsen, J.K. Tourism development strategy or just brown signage? Comparing road administration policies and designation procedures for official tourism routes in two Scandinavian countries. Land Use Policy 2014, 36, 342-350. [CrossRef]

7. ICOMOS. Charter for the interpretation and presentation of cultural heritage site. In Proceedings of the 16th General Assembly of ICOMOS, Québec, QC, Canada, 4 October 2008.

8. Tilden, F. Interpreting Our Heritage; University of North Carolina Press: Chapel Hill, NC, USA, 1977.

9. Papathanassiou-Zuhrt, D.; Karipis, K.; Doumi, M.; Sakellaridis, O. Applying the interpretive planning process to promote local heritage in peripheral areas: Serving the visitor in the Highlands of Nafpaktia, Greece. In Proceedings of the International Conference on Advances in Tourism Economics, Vila Nova de Sto André, Portugal, 13-14 April 2007.

10. Copeland, T.; Delmaire, Y. Heritage Intepretation in the Framework of the European Heritage Days; Report of the Training Course 2003 for European Heritage Days Coordinators; Council of Europe: Strasbourg, France, 2004. 
11. Carter, J. A Sense of Place. An Interpretive Planning Handbook, 1st ed.; Tourism and Environment Initiative: Inverness, UK, 1997.

12. Veverka, J. Interpretive Master Planning; Falcon Press: La Habra, CA, USA, 1998.

13. De Montis, A.; Ledda, A.; Ganciu, A.; Serra, V.; de Montis, S. Recovery of rural centres and "albergo diffuso": A case study inSardinia, Italy. Land Use Policy 2015, 47, 12-28. [CrossRef]

14. Porto, S.M.C.; Cascone, G. Indicatori per la valutazione della potenzialità turistico-ricettiva di edifici rurali tradizionali. J. Agric. Eng. 2008, 4, 43-56. (In Italian)

15. Gutierrez Rodriguez, L.; Ruiz Perez, M.; Yang, X.; Geriletu. From Farm to Rural Hostel: New Opportunities and Challenges Associated with Tourism Expansion in Daxi, a Village in Anji County, Zhejiang, China. Sustainability 2011, 3, 306-321. [CrossRef]

16. Fuentes, J.M.; Gallego, E.; García, A.I.; Ayuga, F. New uses for old traditional farm buildings: The case of the underground wine cellars in Spain. Land Use Policy 2010, 27, 738-748. [CrossRef]

17. Porto, S.M.C.; Cascone, G. A building characterization-based method for the advancement of knowledge on external architectural features of traditional rural buildings. Inf. Constr. 2013, 65, 481-496.

18. Briedenhann, J.; Wickens, E. Tourism routes as a tool for the economic development of rural areas-vibrant hope or impossible dream? Tour. Manag. 2004, 25, 71-79. [CrossRef]

19. Meyer-Cech, K. Regional Cooperation in Rural Tourism Trails. In Rural Tourism and Sustainable Business; Hall, D., Kirkpatrick, I., Mitchell, M., Eds.; Channel View Publications: Clevedon, UK, 2005; pp. 137-148.

20. Porto, S.M.C.; Leanza, P.M.; Cascone, G. Developing Interpretation Plans to Promote Traditional Rural Buildings as Built Heritage Attractions. Int. J. Tour. Res. 2012, 14, 421-436. [CrossRef]

21. Prideaux, B. Creating rural heritage visitor attractions-The Queensland heritage trails project. Int. J. Tour. Res. 2002, 4, 313-323. [CrossRef]

22. Gokovali, U.; Bahar, O.; Kozak, M. Determinants of length of stay: A practical use of survival analysis. Tour. Manag. 2007, 28, 736-746. [CrossRef]

23. Jaffe, E.; Pasternak, H. Developing Wine Trails as a Tourist Attraction in Israel. Int. J. Tour. Res. 2004, 6, 237-249. [CrossRef]

24. Josiam, B.M.; Mattson, M.; Sullivan, P. The Historaunt: Heritage tourism at Mickey's Dining Car. Tour. Manag. 2004, 25, 453-461. [CrossRef]

25. Plummer, R.; Telfer, D.; Hashimoto, A.; Summers, R. Beer tourism in Canada along the Waterloo-Wellington Ale Trail. Tour. Manag. 2005, 26, 447-458. [CrossRef]

26. Yang, Z.; Cai, J.; Sliuzas, R. Agro-tourism enterprises as a form of multi-functional urban agriculture for peri-urban development in China. Habitat Int. 2010, 34, 374-385. [CrossRef]

27. Ankomah, P.K.; Crompton, J.L.; Baker, D. Influenze of cognitive distance in vacation choice. Ann. Tour. Res. 1996, 23, 138-150. [CrossRef]

28. Getz, D.; Brown, G. Critical success factors for wine tourism regions: A demand analysis. Tour. Manag. 2006, 27, 146-158. [CrossRef]

29. Leone, G. Donnafugata Il Castello; Filippo Angelica Editore: Siracusa, Italy, 2006.

30. Anselmi, G.F.; Arezzo di Trifiletti, G.; Vella, C.; Turco, T. Il Castello di Donnafugata a Ragusa; Edizioni Kalós: Palermo, Italy, 2002.

31. Ingallinera, F. Castello Donnafugata dall'alto, Available online: http://www.panoramio.com/photo/4129944 (accessed on 17 December 2015).

32. Curtis, E. Interpretive Project Guide Book; U.S.D.A. Forest Service: Portland, Italy, 1994.

33. Izquierdo-Tugas, P.; Tresserras, J.J.; Matamala-Mellini, J.C. Heritage Interpretation Centres. The HICIRA Handbook; Institut d'Edicions de la Diputació de Barcelona: Diputació de Barcelona, Spain, 2005.

34. Lew, A.; McKercher, B. Trip destinations, gateways and itineraries: The example of Hong Kong. Tour. Manag. 2002, 23, 609-621. [CrossRef]

35. Lew, A.; McKercher, B. Modeling tourist movements: A Local Destination Analysis. Ann. Tour. Res. 2006, 33, 403-423. [CrossRef]

36. Kent, R.L.; Elliott, C.L. Scenic ruotes linking and protecting natural and cultural landscape features: A greenway skeleton. Landsc. Urban Plan. 1995, 33, 341-355. [CrossRef]

37. Ramírez, Á.; Ayuga-Téllez, E.; Gallego, E.; Fuentes, J.M.; García, A.I. A simplified model to assess landscape quality from rural roads in Spain. Agric. Ecosyst. Environ. 2011, 142, 205-212. [CrossRef] 
38. Clius, M.; Teleucă, A.; David, O.; Moroşanu, A. Trail accessibility as a tool for sustainable management of protected areas: Case study Ceahlău National Park, Romania. Procedia Environ. Sci. 2012, 14, 267-278. [CrossRef]

39. Min, J.C.H. A short-form measure for assessment of emotional intelligence for tour guides: Development and evaluation. Tour. Manag. 2012, 33, 155-167. [CrossRef]

40. Rabotić, B. Tourist Guides as Cultural Heritage Interpreters: Belgrade Experience with Municipality-sponsored Guided Walks for Local Residents. In Proceedings of the Cultural and Event Tourism: Issues \& Debates, Alanya, Turkey, 5-9 November 2008; pp. 213-233.

41. Yu, X.; Weiler, B.; Ham, S. Cultural Mediation in Guided Tour Experiences: A Case Study of Australian Guides of Chinese Tour Groups; Monash University: Melbourne, Australia, 2004; Volume 44, p. 12.

42. Zhang, H.Q.; Chow, I. Application of importance-performance model in tour guides' performance: Evidence from mainland Chinese outbound visitors in Hong Kong. Tour. Manag. 2004, 25, 81-91. [CrossRef]

43. Chen, C.-F.; Tsai, D. How destination image and evaluative factors affect behavioral intentions? Tour. Manag. 2007, 28, 1115-1122. [CrossRef]

44. Chen, C.-F.; Chen, F.-S. Experience quality, perceived value, satisfaction and behavioral intentions for heritage tourists. Tour. Manag. 2010, 31, 29-35. [CrossRef]

45. De Rojas, C.; Camarero, C. Visitors' experience, mood and satisfaction in a heritage context: Evidence from an interpretation center. Tour. Manag. 2008, 29, 525-537. [CrossRef]

46. Denstadli, J.M.; Jacobsen, J.K.S. The long and winding roads: Perceived quality of scenic tourism routes. Tour. Manag. 2011, 32, 780-788. [CrossRef]

47. Murphy, P.; Pritchard, M.P.; Smith, B. The destination product and its impact on traveller perceptions. Tour. Manag. 2000, 21, 43-52. [CrossRef]

48. Nowacki, M.M. Quality of Visitor Attractions, Satisfaction, Benefits and Behavioural Intentions of Visitors: Verification of a Model. Int. J. Tour. Res. 2009, 11, 297-309. [CrossRef]

49. Devesa, M.; Laguna, M.; Palacios, A. The role of motivation in visitor satisfaction: Empirical evidence in rural tourism. Tour. Manag. 2010, 31, 547-552. [CrossRef]

50. Hernández Maestro, R.M.; Muñoz Gallego, P.A.; Requejo, L.S. The moderating role of familiarity in rural tourism in Spain. Tour. Manag. 2007, 28, 951-964. [CrossRef]

(C) 2016 by the authors; licensee MDPI, Basel, Switzerland. This article is an open access article distributed under the terms and conditions of the Creative Commons by Attribution (CC-BY) license (http://creativecommons.org/licenses/by/4.0/). 